\title{
Counterurbanization: A neglected pathway of forest transition
}

\author{
Yohana G. Jimenez $(\mathbb{D}$, Ezequiel Aráoz $\mathbb{1}$, Romina D. Fernandez, \\ Sofia Nanni, Ramiro Ovejero, Leonardo Paolini, H. Ricardo Grau (D)
}

Received: 27 May 2021/Revised: 1 September 2021/Accepted: 12 September 2021 / Published online: 22 October 2021

\begin{abstract}
Human settlement into rural areas (counterurbanization) is generating new patterns of reforestation, with distinctive features compared to the previously considered pathways of forest transition through "economic development" and "forest scarcity". Here, we discuss the specific features of this neglected pathway of forest recovery and describe the process with the support of study cases around the world. This pathway includes specific motivations (e.g., natural amenities, outdoor recreation), particular socio-economic processes, conflicts between newcomers and locals, and specific ecological outcomes (e.g., a larger proportion of non-native species in the new forests). Although this pathway locally affects small areas, as a widespread and expanding process around the world, counterurbanization could have a growing global effect, with the potential to modify biodiversity, ecosystem services, and cultural values. These novel characteristics should be further explored to better understand the patterns and processes of forest transitions in a context of a globally connected world.
\end{abstract}

Keywords Amenity migration - Anthropocene ·

Exurbanization - Non-native species · Novel ecosystems . Plant invasion

\section{INTRODUCTION}

The forest transition (FT, Mather 1992), the temporal change from net forest loss to net forest gain in a region, is characteristically driven by socio-economic changes. Two

Supplementary Information The online version contains supplementary material available at https://doi.org/10.1007/s13280021-01632-9. major pathways have been identified (Rudel et al. 2005), (1) economic development, which leads to agricultural disintensification in relatively marginal areas where spontaneous secondary forest succession subsequently takes place, and (2) scarcity of forest resources, which favors the expansion of tree plantations. Counterurbanization, neglected as a pathway of forest transition, may lead to forest recovery at local scale but becoming more widespread all over the world (McCarthy 2008; Ravetz et al. 2012; Taylor and Hurley 2016). Although the pathway we describe shares some features with both "classic" pathways, it also has particular features in terms of drivers, and social-ecological consequences.

Counterurbanization- often referred to as exurbanization, dispersed urbanization or amenity migration- is here approached as the increase in low-density settlements in rural areas, due to the temporal or permanent relocation of the urban population in the countryside (Mitchell 2004). Counterurbanization is indirectly driven by large-scale socio-economic and cultural changes, particularly the transition from manufacturing to service- and knowledgebased development (Ravetz et al. 2012; Taylor and Hurley 2016). In this context, the social perception of nature changes from valuing mainly resource extraction (e.g., timber, wood, agricultural products, water, soil) to a nonmaterial value (e.g., esthetic, spiritual, inspirational, recreational); and rural environments emerge as important sources of natural amenities. The movement of urbanites to the countryside triggers economic and cultural changes that favor conservation and recreational activities at the time that extractive activities decrease (Taylor and Hurley 2016). Although counterurbanization is a multifaceted process in which residential and recreational uses can contribute to deforestation (e.g., built-up in pristine ecosystems, pastures for horses, Bock and Bock 2009), we 
focus on counterurbanization motivated by the natural amenities in former agricultural areas. In these landscapes, forest often expands on abandoned farmlands.

This perspective paper aims to bring together research on social sciences, land use/cover change and plant invasion to depict the FT counterurbanization pathway. We use scientific literature to achieve a general understanding of this pathway -and its outcomes- and we also used documented case studies (Fig. 1 and Table 1) to illustrate different mechanisms of counterurbanization around the world. To achieve this, the paper is organized into four main sections: (1) we first summarize the two "classic" forest transition pathways; (2) we present the counterurbanization forest transition pathway, comparing it with the traditional ones in terms of land cover patterns and new forest species composition. Based on the above, (3) we discuss socio-economic and environmental outcomes of each pathway. Finally, (4) we discuss emerging questions and research that would be necessary to improve our understanding of this process.

\section{ECONOMIC DEVELOPMENT AND SCARCITY FOREST TRANSITION PATHWAYS}

Forest transition has been documented at least since the late 18th century (Mather 1992), but it has accelerated and expanded in the last decades (Meyfroidt and Lambin 2011). Records of forest transition occurred in Europe and the United States in the 18-20th century, represented mainly by an increase in forest plantations. Currently, in these regions, most of the lands with forest regrowth potential have been colonized by woody species (Mather 1992; Meyfroidt and Lambin 2011). More recently (i.e., late 20th century) spontaneous FT and tree plantation expansion has been documented in rural and peri-urban areas of Latin America and Asia (Ashraf et al. 2017; Wilson et al. 2017; Nanni et al. 2019). Rudel et al. (2005) described two forest transition pathways that are currently widely recognized: (1) The "economic development" pathway results in spontaneous forest transition as a consequence of rural outmigration and agricultural dis-intensification, (2) The "forest scarcity" pathway mostly involves expansion of tree plantations as a response to increased demand of timber and other forest products.

The economic development pathway is associated with the national income increase, agricultural adjustment, and rural-urban migration (Meyfroidt and Lambin 2011; Redo et al. 2012). Urban economic growth increases the attractiveness of cities, as they represent opportunities for socioeconomic development and access to employment, education and public services. On the other hand, agricultural mechanization leads to the concentration of croplands on flat and fertile lands, which reduces the demand for rural

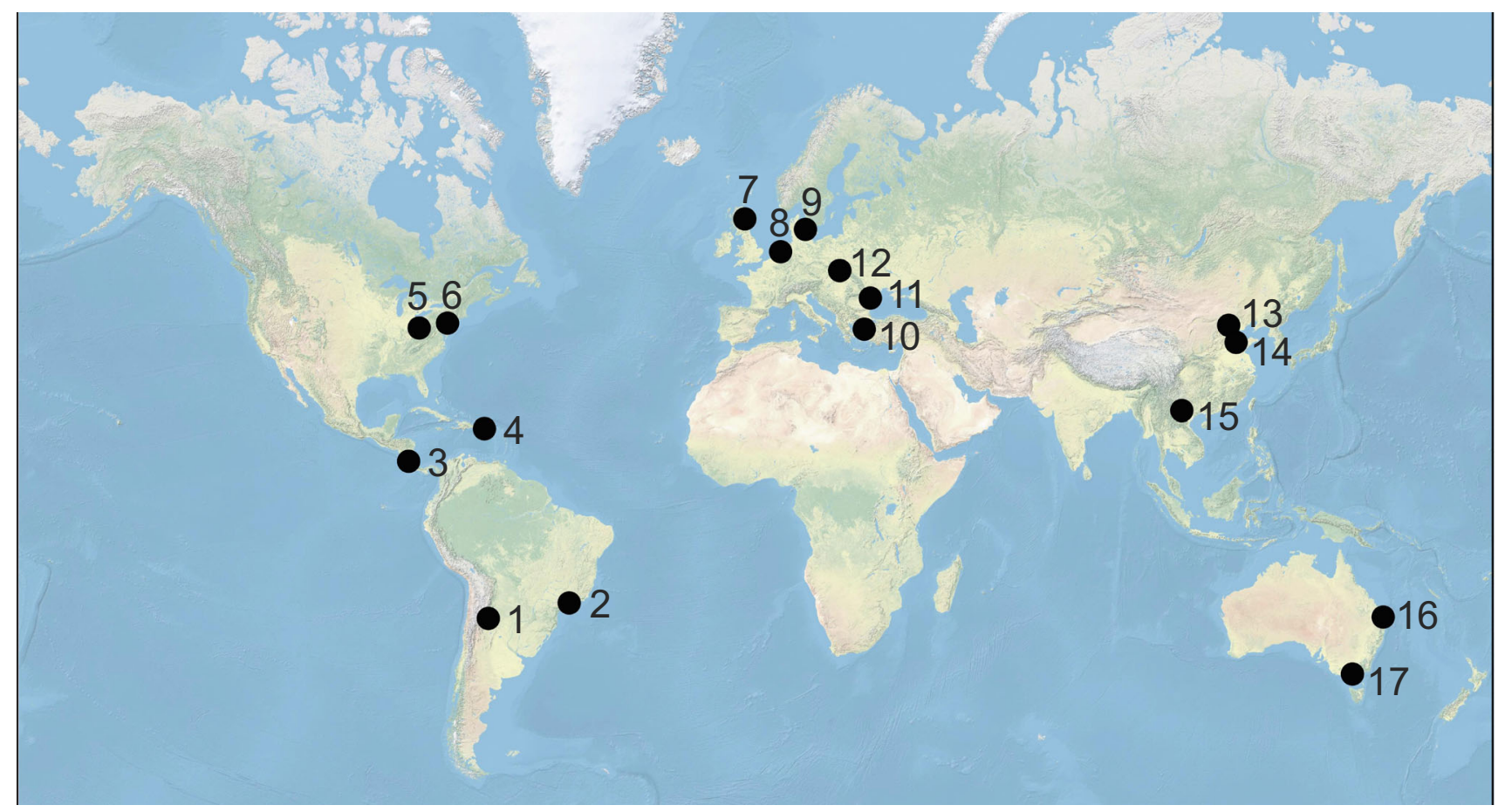

Fig. 1 Geographic localization of the 17 case studies considered in this work (details of case studies are in Table 1, to display the location of case studies in an Earth browser, access to a KML file (Keyhole Markup Language) in "Electronic supplementary material" 


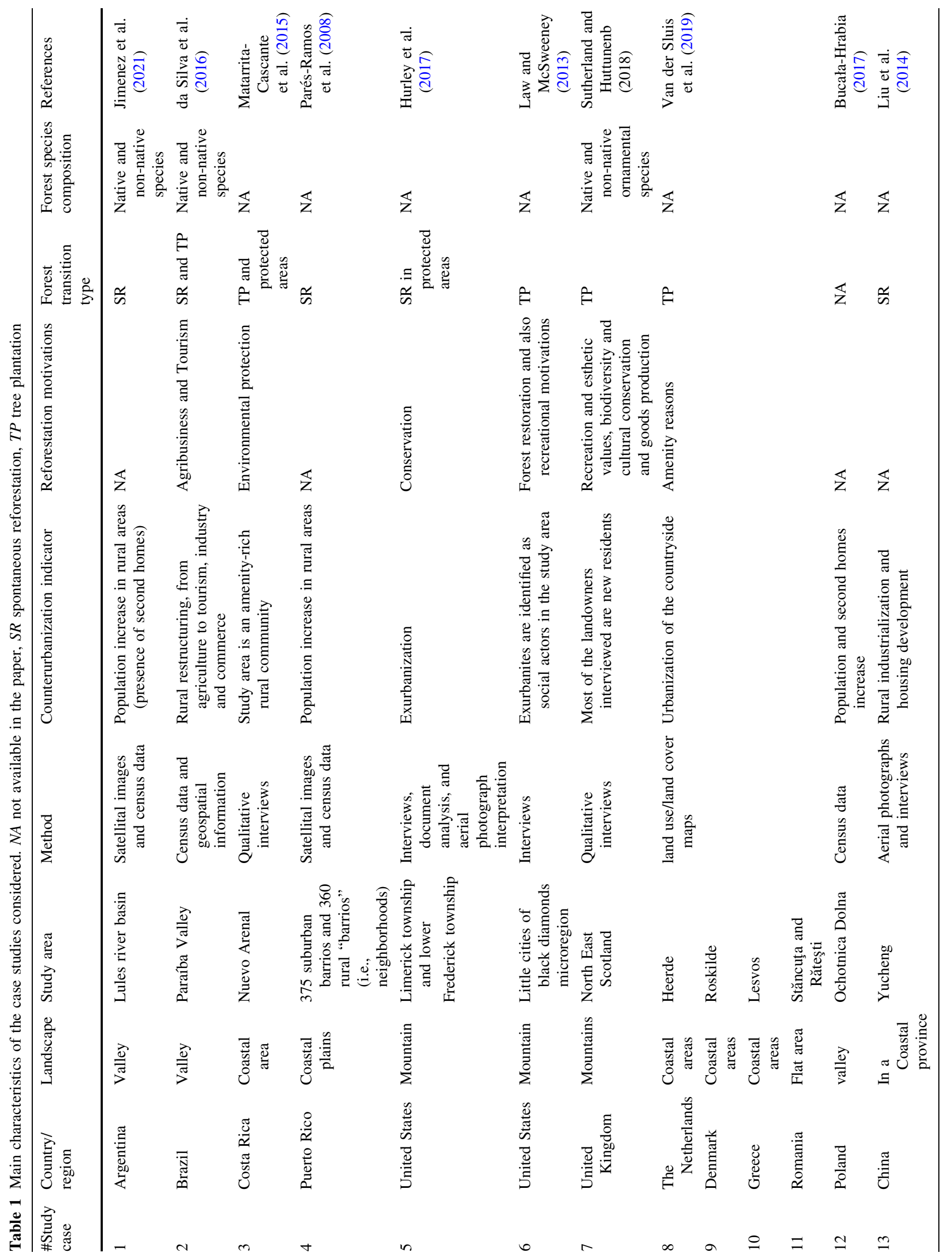




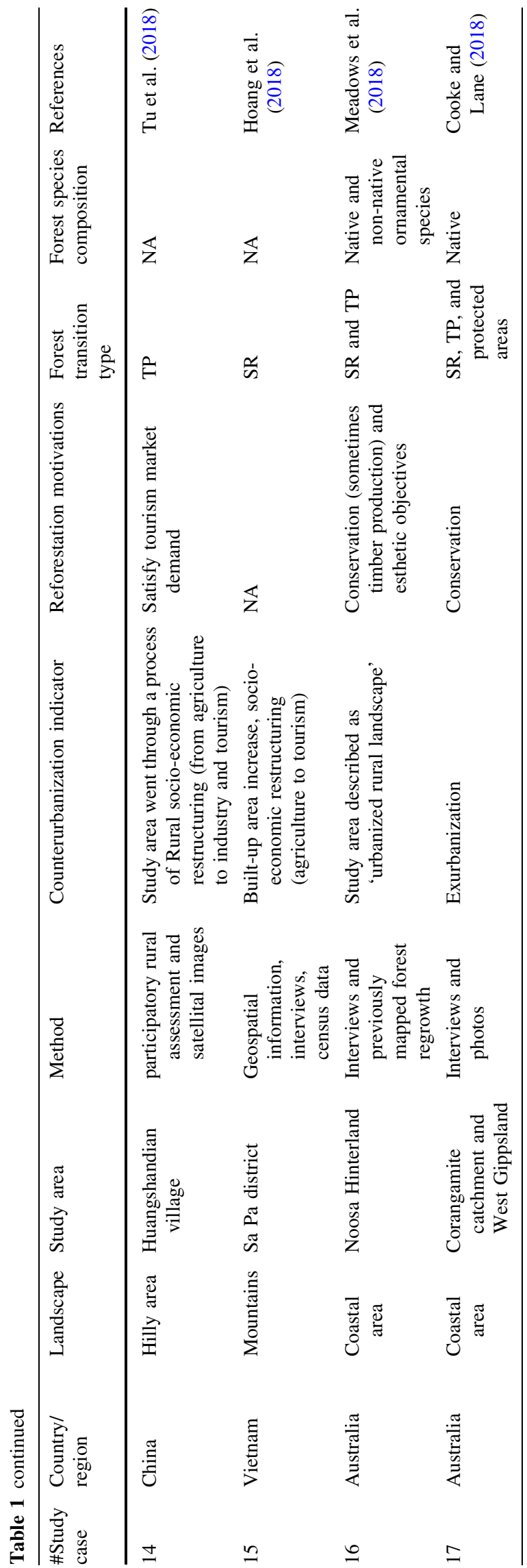

labor and the competitiveness of crops produced in less accessible lands with little technification, often managed by small producers (Rudel et al. 2019). The pursuit for human well-being, based on personal/familiar economic growth, is the fundamental driver of rural-urban migration (Rudel et al. 2019), and rural out-migration is associated with forest exploitation reduction (e.g., timber extraction and livestock grazing) and marginal cropland abandonment (Aide and Grau 2004). In areas where labor scarcity cannot be replaced by mechanization (mostly due to rough topography), agriculture tends to dis-intensify or be abandoned, sparing land for forest restoration and the spontaneous expansion of new forests (Meyfroidt and Lambin 2011).

The forest scarcity pathway is associated with a demand for forest goods and services. Forest cover reduction affects the supply of industrial materials (e.g., wood, pulp for paper, bioenergy) and services to the population (e.g., habitat for hunting, flood and erosion regulation) (Meyfroidt and Lambin 2011). In this context, forest plantations increase their profitability, which motivates landowners to replace crops and pastures with trees (Rudel et al. 2005). Currently, tree plantations represent around $7 \%$ of the world's forests, and they continue to expand (5.7 million ha/year between 1990 and 2020, FAO 2020). Reported cases of this pathway identify industrial plantations and reforestation promoted by governments (e.g., China) as the main responsible for the global increase in planted forests (McEwan et al. 2020). In some European countries, planted forests increased due to a decrease in timber importation after the First World War (Meyfroidt and Lambin 2011). There is also forest expansion by small scale plantations managed by local communities. Smallholders replace marginal crops in steep slopes and pastures with tree plantations to reduce labor and increase incomes in a relatively short time (Rudel et al. 2019).

\section{THE COUNTERURBANIZATION PATHWAY}

Counterurbanization is a distinctive feature of developed countries or comparatively developed locations in developing countries: it was registered for the first time in North America, Europe, and Australia in the 1970s when multiple authors identified rural population growth and an increase of low-density urbanizations (Mitchell 2004). In the 1990s, counterurbanization began to be documented also in the Global South (García-Ayllón 2016; Geyer 2018; Tu et al. 2018). Although this urbanization pattern is not new, its potential role in forest transition has not been addressed. We propose that social processes and land cover changes associated with counterurbanization drive forest expansion with particular characteristics (Fig. 2). 


\section{Mechanisms of counterurbanization}

As most land use changes in the anthropocene, counterurbanization depends on globalized markets that influence decision-making and livelihoods, even at local scales (Verburg et al. 2015; Taylor and Hurley 2016; Cooke and Lane 2018). The raising of the service sector (e.g., commerce, tourism, health care, education; and an increased connectivity through transport and communication) in developed countries -or regions- promote rural economy restructuring, which in specific contexts implies a transition from traditional agriculture to nature-based land uses (Woods 2005; Abrams et al. 2012). Urban population revalue nature amenities, and the pursuit of a rural lifestyle and outdoor recreation prompts them to move to the countryside, forming low-density urban systems (Taylor and Hurley 2016; Cooke and Lane 2018; Shaw et al. 2020). The selected destinations combine proximity to developed large urbanizations (which facilitates access to infrastructure, health services and better education) with the environmental services provided by natural areas (Ravetz et al. 2012). Because newcomers have an idyllic perception of nature, they are frequently more motivated to protect or restore forests (Akgün et al. 2011). As counterurbanization progresses, rural economy is re-oriented toward tourism and real estate, strategies to preserve/create green spaces increase and agricultural abandonment accelerates (Woods 2005; Abrams et al. 2012; Shaw et al. 2020). Farming progressively becomes unprofitable in this context and counterurbanization also increases property prices reducing the possibilities of local people to maintain or buy new land (Woods 2005).

We propose counterurbanization-driven forest transition as a hybrid pathway between the forest scarcity and economic development pathways with specific emerging outcomes (Fig. 2). First, newcomers demand natural landscapes, which drives conservation strategies and thus resembles the scarcity pathway (counterurbanizationrecreational demand, case studies $2,3,5,6,7,8,9,10,11$, 138 14, 16 and 17 in Table 1). In addition, the change in rural lifestyle operates similarly to the economic development pathway, favoring the dis-intensification of agriculture, which may drive spontaneous reforestation (counterurbanization-agricultural dis-intensification, case studies 1, 2, 4, 5, 13, 15, 16 and 17 in Table 1). Although there is often a willingness to include only native species when designing these landscapes, non-native plants are frequently incorporated in the new forests (Abrams et al. 2012; Taylor and Hurley 2016), through accidental introductions with population mobility (e.g., tourism) and through the use of ornamental species in home gardens (Dehnen-Schmutz et al. 2007).
Counterurbanization also generates spatial patterns that differ from those of traditional FT pathways. Spontaneous forest transition via economic development has a scattered pattern of forest expansion in areas with reduced accessibility and affects large areas of the landscape; while the forest products scarcity pathway is located in productive, relatively accessible lands that allow the transport of forest products (Malkamäki et al. 2018; Nanni et al. 2019; Rudel et al. 2019). In contrast, FT mediated by counterurbanization is more likely to be spatially localized around accessible low-density residential areas, in places with particularly attractive climate, scenic or cultural amenities (e.g., coastal and mountainous areas, Table 1), and with good connection to developed cities (Ravetz et al. 2012; Taylor and Hurley 2016; Golding and Winkler 2020).

\section{Recreational forest demand}

Socio-economic changes in developed countries lead to new cultural values, increasing the positive perception of nature and demand for forests. However, unlike the forest scarcity pathway, such demand is not primarily for extractive purposes but for their esthetic, recreational and spiritual value (case studies 2, 3, 5, 6, 7, 8, 9, 10, 11, 14, 16 and 17 in Table 1; Hall and Müller 2004; Abrams et al. 2012; Cooke and Lane 2015). In the counterurbanization pathway, socio-cultural services valuation is incorporated into land use planning and management, and leads to an increase in protected forests and multipurpose plantations (case studies: 2, 3, 5, 6, 7, 8, 9, 10, 11, 14, 16 and 17 in Table 1; Hall and Müller 2004; Taylor and Hurley 2016).

Particularly in rural areas where agricultural use is decreasing, certain governments finance or provide legal incentives for the restoration of private lands, which has promoted the creation of protected areas with the aim of contributing to nature-tourism development (Taylor and Hurley 2016; Shaw et al. 2020). For example, the regulation of second-home development in the United States implies that a proportion of private lands must be kept undisturbed to promote conservation. Since these residential areas are commonly established near protected areas, they act as a buffer or expand their effective conservation area, thus contributing to nature conservation (Mockrin et al. 2017). Not only does the government promote reforestation, but new landowners are frequently willing to protect forests with their own funds because they assign a relational (emotional link with the landscape) or esthetic value to nature (case studies: 3, 5 and 14 in Table 1; Taylor and Hurley 2016; Shaw et al. 2020).

Active reforestation (tree plantations) for esthetic purposes has also become popular as a strategy to promote green tourism (case studies: 6, 7, 8, 9, 10, 11 and 14 in Table 1; Bock and Bock 2009). The design of these forests 


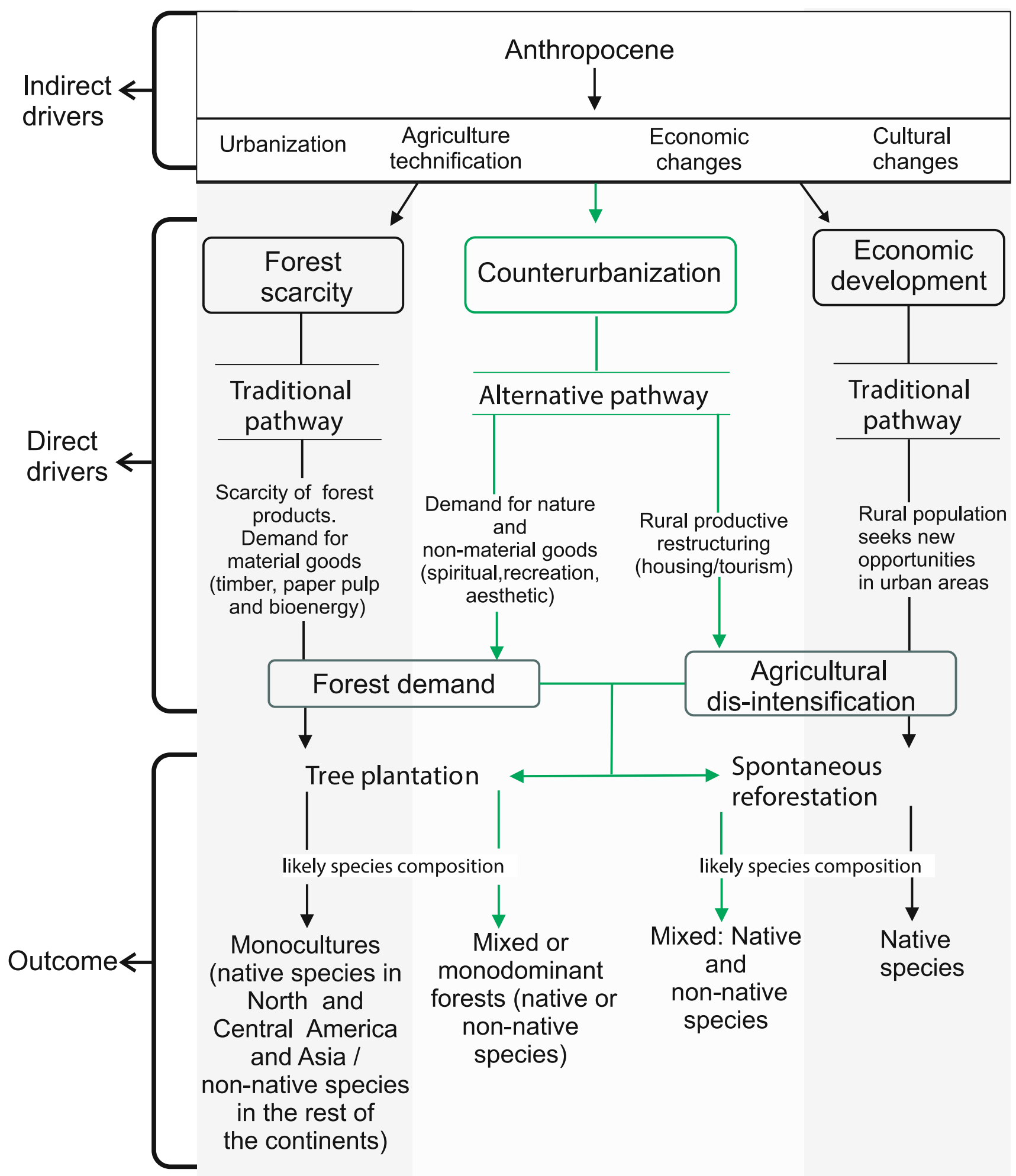

Fig. 2 Conceptual model of the different forest transition pathways

can vary among sites, according to the way in which nature is perceived by society: some people find scenic beauty in native species, while others prefer novel / unfamiliar landscapes dominated by non-native species (Kueffer and Kull 2017). For example, in some rural lands of Europe, newcomers planted native trees in order to conserve native 
biodiversity but also increase scenic views and promote forest cultural activities such as bird watching (case study 7 in Table 1). In contrast, some rural landscapes of Australia were reforested with non-native species which had esthetic value for landowners and were frequently used in gardens (case study 16 in Table 1).

\section{Agricultural dis-intensification}

Dis-intensification of agriculture in marginal areas (mostly due to steep slopes) in the context of socio-economic development is a well-known driver of forest transition. Counterurbanization often occurs in mountain and coastal settings which provide attractive landscapes and climatic conditions. In these contexts, urban developments compete for land with agriculture, and although rural out-migration might not occur in the counterurbanization pathway, economic restructuring toward the service sector outcompetes agriculture and livestock ranching (case studies 1, 2, 4, 5, 13, 15, 16 and 17 in Table 1; Woods 2005; Cooke and Lane 2015). Thus, local people frequently stay close to counterurbanizations and abandon farm activities to work in these emerging economic activities (Akgün et al. 2011). The availability of land with reduced intensity of agricultural use and seed sources allows the forest transition. Therefore, unlike the economic development pathway described by Rudel et al. (2005), in which rural dis-intensification usually occurs in remote areas, counterurbanization drives this process in arable lands located in populated, accessible areas.

In the counterurbanization pathway, non-native species are likely to be a key component of new forests (Kulmatiski 2006; Bock and Bock 2009). In the case studies we identified to exemplify this pathway, only five detailed the species composition; and of these, four included ornamental non-native species (case studies 1, 2, 7 and 12 in Table 1). Beyond these case studies, plant invasion studies have already demonstrated the role of urbanization and human population in the introduction and spread of nonnative species (Taylor and Irwin 2004; Dehnen-Schmutz et al. 2007; Spear et al. 2013). For example, Taylor and Irwint (2004) demonstrated that real estate development has a strong and positive effect on the number of nonnative plant species. Even in protected areas, the proximity to the human population was found to increase non-native species richness (Spear et al. 2013). Non-native tree species are mainly introduced for ornamental purposes, and they frequently establish in abandoned agricultural lands (Dehnen-Schmutz et al. 2007; Bock and Bock 2009). Once introduced, the probability of colonization of non-native species is potentially high in counterurbanized areas compared to cities because gardens would be closer to the abandoned lands (Marco et al. 2008).

\section{EXPECTED OUTCOMES OF THE FOREST TRANSITION PATHWAYS}

\section{Socio-cultural impact}

In the economic development pathway, decreasing agricultural profitability and urban development drive rural people out-migration (Rudel et al. 2019). The reduction of the family group limits activities that require manual labor, while migrants usually send remittances to their family for rural subsistence or investment in more profitable practices that may lead to declines in traditional farming (Hecht and Saatchi 2007). Although some stakeholders perceive an increase in the esthetic and recreational value of spontaneous reforestation as a consequence of out-migration, the contribution of the landscape to cultural identity is reduced, because migrating and remaining people drop traditional practices and lose the sense of place and cultural heritage (Martin-Fores et al. 2020; Table 2).

In the forest scarcity pathway, large-scale tree plantations have different impacts on local communities. In some cases, when families do not have property titles, land price increase around plantations forces them to out-migrate; land management by the government or private companies may restrict access to natural forests and thus limit community traditional practices (e.g., hunting or livestock ranching, Malkamäki et al. 2018). On the other hand, rural populations can benefit from infrastructure improvement, and employment opportunities increase due to the demand for labor on plantations, although these may be precarious and temporary jobs (Charnley 2006; Malkamäki et al. 2018; Table 2).

In the counterurbanization pathway local economic benefits arise when urbanites migrate to the countryside or carry out infrastructure development in rural areas, leading to emerging labor opportunities for local families (Woods 2005; Akgün et al. 2011; Taylor and Hurley 2016). However, counterurbanization also triggers socio-cultural conflicts between newcomers and local residents. For example, the increase in property prices and living costs reduces the possibility of purchasing land for the local young population and might force them to out-migrate (McCarthy 2008; Golding and Winkler 2020). In some cases, newcomers oppose traditional activities and try to impose their values and ideals on the rural community (Woods 2005; Golding and Winkler 2020; Shaw et al. 2020). The increase in land prices leads to the consolidation of property rights in areas in which they were previously loose. New residents start to delimit their properties with fences, restricting access to the local communities and their activities, such as livestock grazing or firewood collection (Hall and Müller 2004; Bock and Bock 2009). Although newcomers usually look forward to close interactions with natural environments, 
some unexpected negative interactions between wildlife and people arise when housing and natural ecosystems are interspersed: e.g., fear of attacks by large carnivores, traffic accidents caused by wildlife (e.g., deer), or domestic animal predation (Evans et al. 2014; Soulsbury and White 2015).

Urban expansion in rural areas may also lead to sociocultural homogenization, loss of rural identity and a decrease in traditional practices (Hall and Müller 2004; Fang 2020). However, new landscapes can lead to increasing human-nature interactions and that some local traditions are reinvigorated to promote tourism (e.g., music, food and dance; Hall and Müller 2004; Fang 2020; Table 2).

\section{Biodiversity and ecosystem services}

Species composition and ecosystem services of new forests depend on multiple factors (e.g., propagules availability, soil properties, landscape connectivity, previous uses) that can lead to completely novel ecosystems (Hobbs et al. 2009; Morse et al. 2014). In this section, we discuss the environmental outcomes of the forests emerging under the three pathways (Table 2).

In the economic development pathway, new forests typically have greater biodiversity than previous agricultural landscapes, although secondary forests take a long time (decades to centuries) to reach primary forest structure and diversity (Wilson et al. 2017; Chazdon et al. 2020). Population reduction and passive reforestation also lead to an increase in wildlife because hunting pressure and fragmentation decrease and shelter availability increases (Navarro and Pereira 2015; Chazdon et al. 2020).

Spontaneous reforestation contributes to carbon sequestration, watershed conservation (Wilson et al. 2017; Chazdon et al. 2020), improves air quality and increases medicinal resources (through an increase in genetic diversity, Martin-Fores et al. 2020). Although reforestation reduces water yields due to an increased evapotranspiration, in the long term the pre-deforestation water levels are likely to be restored (Filoso et al. 2017). Also, as forest transition progresses, surface runoff decreases and soil erosion in secondary forests are reduced to similar levels to those of mature forests (Labrière et al. 2015).

In the forest scarcity pathway, plant biodiversity recovery is often comparatively lower since most tree plantations are dominated by a single species and in approximately $44 \%$ of the cases are non-native species (FAO 2020). Furthermore, this share is even higher in some regions of the southern hemisphere (e.g., in South America, $97 \%$ of the plantations are of introduced species, FAO 2020). However, tree plantations (especially with understory species) increase landscape connectivity, favoring wildlife movement and offering nesting, food and shelter for birds. Plantations can also act as buffers, reducing edge effects in native forests and indirectly contributing to preserving biodiversity (Brockerhoff et al. 2008; Paviolo et al. 2018; Pliscoff et al. 2020).

Tree plantations are generally dominated by fast-growing species, thus carbon sequestration and other provisioning services (e.g., timber, pulpwood and biomass for energy) are greater compared to spontaneous native reforestation (McEwan et al. 2020). Regulating ecosystem services provided by tree plantations depend on species composition and on the characteristics of the landscape. For example, Eucalyptus plantations have a high rate of water consumption; thus, they significantly reduce water yield while controlling soil erosion (Sun et al. 2018). Another important example with contrasting effects on ecosystem services of different regions are pine plantations. In high altitude paramo grasslands of Ecuador, these plantations were found to decrease soil carbon and nitrogen concentrations and reduce water storage capacity of the system (Farley 2008). On the other hand, in erosion-prone areas of Argentina, pine plantations increased water regulation services and soil protection (Wilson et al. 2017).

Counterurbanization pathway gives rise to novel systems through the introduction of non-native species, and it may lead to biotic homogenization (Bock and Bock 2009; Abrams et al. 2012; Morse et al. 2014; Groffman et al. 2017; Jimenez et al. 2021). For example, urban, suburban, and exurban areas of the United States have similar species composition, even though they are separated by large distances. Locally these residential areas increase their plant species richness because they include non-native plants with esthetic appeal, but native biodiversity is reduced (Groffman et al. 2017). The introduction of non-native plants also creates conditions that favor evolutionary diversification (e.g., via hybridization between native and non-native species) (Thomas 2015; Socolar et al. 2016; Vellend et al. 2017). It has also been shown that lowdensity counterurbanization can have positive effects on animal biodiversity (insects, birds and mammals), especially when there is a newcomer attitude toward conservation (Hansen et al. 2005; Bock and Bock 2009), although their species composition differs from natural environments with a high proportion of urban adapted species (Suarez-Rubio et al. 2011). Also, certain negative outcomes for wildlife, such as disease transmission by domestic animals, or reduction of top carnivore and ungulate populations due to fences and roads could also occur (Hansen et al. 2005; Kauffman et al. 2021).

Newcomers of counterurbanized areas often assign high value to cultural services including esthetic landscapes and historical heritage (Woods 2005; Duke et al. 2016; Davis et al. 2021).Counterurbanization FT provides ecosystem 
Table 2 Summary of most likely impacts of the different forest transition pathways. The arrows indicate the direction (red, decrease; green increase) of the effects on social-cultural aspects and biodiversity and ecosystem services. The sign "-" represents a null effect. The relative magnitude of the effect is represented by color intensity

Forest scarcity Economic development Counterurbanization

$\begin{array}{ll}\text { Socio-cultural aspects } & \text { Traditional activities } \\ \text { Biodiversity and ecosystem services } & \text { Social conflicts } \\ & \text { Animal species richness } \\ & \text { Hydric regulation } \\ \text { Soil protection } & \text { Climatic regulation } \\ \text { Esthetic value/recreation }\end{array}$

regulating services similar to those reported in traditional FT pathways, including carbon sequestration (particularly when fast-growing species are introduced), floods mitigation,watershed protection, timber supply and wildlife habitat (Huang et al. 2014; Duke et al. 2016; Davis et al. 2021). However, as new forests associated with counterurbanization expand in populated areas, the number of beneficiaries of local scale ecosystem services would be greater.

\section{TOWARD FURTHER ASSESSMENT OF THE COUNTERURBANIZATION FOREST TRANSITION PATHWAY}

Most of the counterurbanization studies have been conducted in the United States and Europe, where exurbanizations are widespread (Hansen et al. 2005; Groffman et al. 2017; Golding and Winkler 2020). Currently the counterurbanization process is spreading in different regions around the world at accelerated rates, which are even higher than urban cores (McCarthy 2008; Ravetz et al. 2012; Taylor and Hurley 2016; Shaw et al. 2020). As the economy of services and nature-based tourism increases, and as cultural shifts toward a high value of nature keep occurring (Winter et al. 2020), counterurbanization will be a more frequent land use change, with impacts on rural land covers and lifestyles (Ravetz et al. 2012; Golding and Winkler 2020). This will be facilitated by the proliferation of teleworking through good internet connection. The spread of Covid 19 during the last two years will probably speed up the counterurbanization process, as many previously reluctant individuals and organizations will be more open to teleworking scheme (Daniels 2021; Frumkin 2021).

To a great extent, the consequences of counterurbanization depend on the motivations and collective knowledge about the environment of the new inhabitants. Several studies have reported the loss of habitat and fragmentation associated with this process, while others have found positive impacts in forest cover, biodiversity, and ecosystem services in counterubanized areas (Taylor and Hurley 2016; Shaw et al. 2020). Therefore, the results of counterurbanization are highly heterogeneous and may result in totally opposite scenarios. A systematic typification and identification of variables leading toward different outputs is a research priority.

The cultural background and approach toward nature of exurbanites in different societies may shape the forest transition pathway. However, counterurbanization is usually led by a specific socio-economic group (upper-middleclass). This group has increased access to technical and 
economic resources, information and education, which increases the opportunities of replicating successful experiences and reducing undesired environmental effects. Despite commonalities of this socio-economic category, cultural differences are likely in different countries, regions and socio-ecological contexts, that likely result in different outputs and need to be further explored.

Analyzing the motivations of migrants, the diversity of the counterurbanization process (e.g., housing density, main economic activities, conservation strategies, land use management) and the impacts on forest transition features (e.g., species composition, ecosystem functions and extension of the new forests), will allow a deep understanding of this pathway. In addition to the environmental outcomes, each rural community has its own cultural identity, thus the social impacts of forest transition mediated by counterurbanization could vary greatly from one place to another. We hope the drivers and consequences that we described here can act as working hypotheses to refine the understanding of the expanding process, which would be useful to improve environmental quality and social well-being around the world.

\section{CONCLUSIONS}

Counterurbanization often promote local forest expansion due to land use changes leading to marginal agriculture disintensification and an increasing valuation of nature, thus resulting in a distinctive forest transition pathway. Counterurbanization is associated with socio-economic development, urban-like population increase in rural areas, diversification of productive activities, abandonment of marginal agriculture, and demand for attractive natural landscapes. This hybrid pathway of forest transition combines features of previously recognized pathways ("economic development" and "forest scarcity"), but also includes distinctive characteristics. Emerging forests tend to present an aggregated pattern around accessible, lowdensity residential areas with natural appeal, which are generally connected to larger prosperous cities. Often, they include a large share of non-native species that generate novel biotic communities and landscapes. Although there are positive contributions of non-native plants to ecosystem services and they might even increase local plant species richness, if they become invasive, they may lead to landscape homogenization. Regardless of the pathway, forest expansion often leads to increases in regulating services, although this varies widely according to the context and tree species identity. Although FT through counterurbanization is a spatially restricted process, it is taking place in various regions of the world. Given the current socioeconomic and cultural trends, and ecological globalization
(McCarthy 2008), this process will likely accelerate in the future, creating scattered but widespread new ecosystems with novel environmental and cultural outcomes. The drivers and consequences here described can act as working hypotheses to lead further multidisciplinary empirical studies in order to refine the understanding of the expanding process.

Acknowledgements We thank the anonymous reviewers and the editor for the valuable comments that led to a significant improvement of this paper.

Author contributions YGJ, EA, and HRG: Conceptualization. YGJ, EA, HRG, RDF, ASN, RO, and LP: Investigation. HRG and EA: Supervision. YGJ: Writing-original draft. YGJ, EA, HRG, RDF, ASN, RO, and LP: Writing-review \& editing.

\section{REFERENCES}

Abrams, J.B., H. Gosnell, N.J. Gill, and P.J. Klepeis. 2012. Recreating the rural, reconstructing nature: An international literature review of the environmental implications of amenity migration. Conservation and Society 10: 270-284. https://doi. org/10.4103/0972-4923.101837.

Aide, M., and H.R. Grau. 2004. Globalization, migration, and Latin American ecosystems. Science 305: 1915-1916. https://doi.org/ 10.1126/science. 1103179.

Akgün, A.Y.A., T.N. Baycan-Levent, P. Nijkamp, and J. Poot. 2011. Roles of local and newcomer entrepreneurs in rural development: A comparative meta-analytic study. Regional Studies 45: 1207-1223. https://doi.org/10.1080/00343401003792500.

Ashraf, J., R. Pandey, and W. de Jong. 2017. Assessment of biophysical, social and economic drivers for forest transition in Asia-Pacific region. Forest Policy and Economics 76: 35-44. https://doi.org/10.1016/j.forpol.2016.07.008.

Bock, C.E., and J.H. Bock. 2009. Biodiversity and residential development beyond the urban fringe. In The Planner's Guide to Natural Resource Conservation, ed. A. Esparza and G. McPherson. New York: Springer. https://doi.org/10.1007/978-0387-98167-3_4.

Brockerhoff, E.G., H. Jactel, J.A. Parrotta, C.P. Quine, and J. Sayer. 2008. Plantation forests and biodiversity: Oxymoron or opportunity? Biodiversity and Conservation 17: 925-951. https://doi. org/10.1007/s10531-008-9380-x.

Bucała-Hrabia, A. 2017. Long-term impact of socio-economic changes on agricultural land use in the Polish Carpathians. Land Use Policy 64: 391-404. https://doi.org/10.1016/j.landusepol. 2017.03.013.

Charnley, S. 2006. Industrial plantation forestry: Do local communities benefit? Journal of Sustainable Forestry 21: 35-57. https:// doi.org/10.1300/J091v21n04_04.

Chazdon, R.L., D. Lindenmayer, M.R. Guariguata, R. Crouzeilles, J.M.R. Benayas, and E.L. Chavero. 2020. Fostering natural forest regeneration on former agricultural land through economic and policy interventions. Environmental Research Letters 15: 043002. https://doi.org/10.1088/1748-9326/ab79e6.

Cooke, B., and R. Lane. 2015. Re-thinking rural-amenity ecologies for environmental management in the Anthropocene. Geoforum 65: 232-242. https://doi.org/10.1016/j.geoforum.2015.08.007.

Cooke, B., and R. Lane. 2018. Plant-human commoning: Navigating enclosure, neoliberal conservation, and plant mobility in exurban landscapes. Annals of the American Association of Geographers 
108: 1715-1731. https://doi.org/10.1080/24694452.2018. 1453776

da Silva, R.F.B., M. Batistella, and E.F. Moran. 2016. Drivers of land change: Human-environment interactions and the Atlantic forest transition in the Paraíba Valley, Brazil. Land Use Policy 58: 133-144. https://doi.org/10.1016/j.landusepol.2016.07.021.

Daniels, T.L. 2021. Re-designing America's suburbs for the age of climate change and pandemics. Socio-Ecological Practice Research 3: 225-236. https://doi.org/10.1007/s42532-02100084-5.

Davis, A.Y., A. Freund, S.L. Dumyahn, R. Mendoza, A. Muniz Torres, and M.D. Boone. 2021. Parcel management and perceived ecosystem services and disservices in the exurbs of a midwestern county in the United States. Land 10: 448. https:// doi.org/10.3390/land10050448.

Dehnen-Schmutz, K., J. Touza, C. Perrings, and M. Williamson. 2007. A century of the ornamental plant trade and its impact on invasion success. Diversity and Distributions 13: 527-534. https://doi.org/10.1111/j.1472-4642.2007.00359.x.

Duke, J.M., J. Bruck, S. Barton, M. Murray, S. Inamdar, and D.W. Tallamy. 2016. Public preferences for ecosystem services on exurban landscapes: A case study from the Mid-Atlantic, USA. Heliyon 2: e00127. https://doi.org/10.1016/j.heliyon.2016. e00127.

Evans, M.J., J.E. Hawley, P.W. Rego, and T.A. Rittenhouse. 2014. Exurban land use facilitates human-black bear conflicts. The Journal of Wildlife Management 78: 1477-1485. https://doi.org/ 10.1002/jwmg.796.

Fang, W.T. 2020. Rural tourism. In Tourism in Emerging Economies, ed. W.T. Fang, 103-129. Singapore: Springer. https://doi.org/10. 1007/978-981-15-2463-9_5.

FAO. 2020. The State of the World's Forests 2020 Forests, Biodiversity and People. Rome: FAO. https://doi.org/10.4060/ ca8642en.

Farley, K.A. 2008. Grasslands to tree plantations: Forest transition in the Andes of Ecuador. Annals of the Association of American Geographers 97: 755-771. https://doi.org/10.1111/j.1467-8306. 2007.00581.x.

Filoso, S., M.O. Bezerra, K.C.B. Weiss, and M.A. Palmer. 2017. Impacts of forest restoration on water yield: A systematic review. PLoS ONE 12: e0183210. https://doi.org/10.1371/ journal.pone.0183210.

Frumkin, H. 2021. COVID-19, the built environment, and health. Environmental Health Perspectives 129: 075001. https://doi.org/ 10.1289/EHP8888.

García-Ayllón, S. 2016. Rapid development as a factor of imbalance in urban growth of cities in Latin America: A perspective based on territorial indicators. Habitat International 58: 127-142. https://doi.org/10.1016/j.habitatint.2016.10.005.

Geyer, N.P. 2018. Counterurbanization in South Africa: Measuring migration significance. Regional Science Policy \& Practice 10: 3-14. https://doi.org/10.1111/rsp3.12105.

Golding, S.A., and R.L. Winkler. 2020. Tracking urbanization and exurbs: Migration across the rural-urban continuum, 1990-2016. Population Research and Policy Review 39: 835-859. https:// doi.org/10.1007/s11113-020-09611-w.

Groffman, P.M., M. Avolio, J. Cavender-Bares, N.D. Bettez, J.M. Grove, S.J. Hall, S.E. Hobbie, K.L. Larson, et al. 2017. Ecological homogenization of residential macrosystems. Nature Ecology \& Evolution 1: 1-3. https://doi.org/10.1038/s41559017-0191.

Hall, C.M., and D.K. Müller. 2004. Tourism, Mobility, and Second Homes: Between Elite Landscape and Common Ground, vol. 15. Bristol: Channel View Publications.

Hansen, A.J., R.L. Knight, J.F.M. Marzluff, S. Powell, K. Brown, P.H. Gude, and K. Jones. 2005. Effects of exurban development on biodiversity: Patterns, mechanisms, and research needs. Ecological Applications 15: 1893-1905. https://doi.org/10. 1890/05-5221.

Hecht, S.B., and S.S. Saatchi. 2007. Globalization and forest resurgence: Changes in forest cover in El Salvador. BioScience 57: 663-672. https://doi.org/10.1641/B570806.

Hoang, T.T.H., A. Van Rompaey, P. Meyfroidt, G. Govers, K.C. Vu, A.T. Nguyen, L. Hens, and V. Vanacker. 2018. Impact of tourism development on the local livelihoods and land cover change in the Northern Vietnamese highlands. Environment, Development and Sustainability 22: 1371-1395. https://doi.org/ 10.1007/s10668-018-0253-5.

Hobbs, R.J., E. Higgs, and J.A. Harris. 2009. Novel ecosystems: Implications for conservation and restoration. Trends in Ecology \& Evolution 24: 599-605. https://doi.org/10.1016/j.tree.2009.05. 012.

Huang, Q., D.T. Robinson, and D.C. Parker. 2014. Quantifying spatial-temporal change in land-cover and carbon storage among exurban residential parcels. Landscape Ecology 29: 275-291. https://doi.org/10.1007/s10980-013-9963-0.

Hurley, P.T., M. Maccaroni, and A. Williams. 2017. Resistant actors, resistant landscapes? A historical political ecology of a forested conservation object in exurban southeastern Pennsylvania. Landscape Research 42: 291-306. https://doi.org/10.1080/ 01426397.2016.1267131.

Jimenez, Y.G., E. Aráoz, H.R. Grau, and L. Paolini. 2021. Linking forest transition, plant invasion and forest succession theories: Socioeconomic drivers and composition of new subtropical andean forests. Landscape Ecology 36: 1161-1176. https://doi. org/10.1007/s10980-021-01192-Z.

Kauffman, M.J., F. Cagnacci, S. Chamaillé-Jammes, M. Hebblewhite, J.C.G. Hopcraft, J.A. Merkle, T. Mueller, A. Mysterud, et al. 2021. Mapping out a future for ungulate migrations. Science 372: 566-569. https://doi.org/10.1126/science.abf0998.

Kueffer, C., and C.A. Kull. 2017. Non-native species and the aesthetics of nature. In Impact of Biological Invasions on Ecosystem Services Invading Nature Springer Series in Invasion Ecology, vol. 12, ed. M. Vilà and P. Hulme. Cham: Springer. https://doi.org/10.1007/978-3-319-45121-3_20.

Kulmatiski, A. 2006. Exotic plants establish persistent communities. Plant Ecology 187: 261-275. https://doi.org/10.1007/s11258006-9140-5.

Labrière, N., B. Locatelli, Y. Laumonier, V. Freycon, and M. Bernoux. 2015. Soil erosion in the humid tropics: A systematic quantitative review. Agriculture, Ecosystems and Environment 203: 127-139. https://doi.org/10.1016/j.agee.2015.01.027.

Lambin, E.F., and P. Meyfroidt. 2010. Land use transitions: Socioecological feedback versus socio-economic change. Land Use Policy 27: 108-118. https://doi.org/10.1016/j.landusepol.2009. 09.003 .

Law, J., and K. McSweeney. 2013. Looking under the canopy: Rural smallholders and forest recovery in Appalachian Ohio. Geoforum 44: 182-192. https://doi.org/10.1016/j.geoforum.2012.09. 008.

Liu, Y., R. Yang, H. Long, J. Gao, and J. Wang. 2014. Implications of land-use change in rural China: A case study of Yucheng, Shandong province. Land Use Policy 40: 111-118. https://doi. org/10.1016/j.landusepol.2013.03.012.

Malkamäki, A., D. D’Amato, N.J. Hogarth, M. Kanninen, R. Pirard, A. Toppinen, and W. Zhou. 2018. A systematic review of the socio-economic impacts of large-scale tree plantations, worldwide. Global Environmental Change 53: 90-103. https://doi.org/ 10.1016/j.gloenvcha.2018.09.001.

Marco, A., T. Dutoit, M. Deschamps-Cottin, J.F. Mauffrey, M. Vennetier, and V. Bertaudière-Montes. 2008. Gardens in urbanizing rural areas reveal an unexpected floral diversity related to 
housing density. Comptes Rendus Biologies 331: 452-465. https://doi.org/10.1016/j.crvi.2008.03.007.

Martín-Forés, I., S. Magro, A. Bravo-Oviedo, R. Alfaro-Sánchez, J.M. Espelta, T. Frei, E. Valdés-Correcher, C. Rodríguez Fernández-Blanco, et al. 2020. Spontaneous forest regrowth in South-West Europe: Consequences for nature's contributions to people. People and Nature 2: 980-994. https://doi.org/10.1002/ pan3.10161.

Matarrita-Cascante, D., A. Sene-Harper, and G. Stocks. 2015. International amenity migration: Examining environmental behaviors and influences of amenity migrants and local residents in a rural community. Journal of Rural Studies 38: 1-11. https:// doi.org/10.1016/j.jrurstud.2015.01.005.

Mather, A. S. 1992. The forest transition. Area 24: 367-379. https:// www.jstor.org/stable/20003181

McCarthy, J. 2008. Rural geography: Globalizing the countryside. Progress in Human Geography 32: 129-137. https://doi.org/10. 1177/0309132507082559.

McEwan, A., E. Marchi, R. Spinelli, and M. Brink. 2020. Past, present and future of industrial plantation forestry and implication on future timber harvesting technology. Journal of Forestry Research 31: 339-351. https://doi.org/10.1007/s11676-01901019-3.

Meadows, J., J. Herbohn, and N. Emtage. 2018. Forest recovery in an Australian amenity landscape: Implications for biodiversity conservation on small-acreage properties. Biodiversity and Conservation 27: 69-90. https://doi.org/10.1007/s10531-0171422-9.

Meyfroidt, P., and E.F. Lambin. 2011. Global forest transition: Prospects for an end to deforestation. Annual Review of Environment and Resources 36: 343-371. https://doi.org/10. 1146/annurev-environ-090710-143732.

Mitchell, C.J. 2004. Making sense of counterurbanization. Journal of Rural Studies 20: 15-34. https://doi.org/10.1016/S07430167(03)00031-7.

Mockrin, M.H., S.E. Reed, L. Pejchar, and S. Jessica. 2017. Balancing housing growth and land conservation: Conservation development preserves private lands near protected areas. Landscape and Urban Planning 157: 598-607. https://doi.org/10.1016/j. landurbplan.2016.09.015.

Morse, N.B., P.A. Pellissier, E.N. Cianciola, R.L. Brereton, M.M. Sullivan, N.K. Shonka, T.B. Wheeler, and W.H. McDowell. 2014. Novel ecosystems in the Anthropocene: A revision of the novel ecosystem concept for pragmatic applications. Ecology and Society 19: 12. https://doi.org/10.5751/ES-06192-190212.

Nanni, A.S., S. Sloan, T.M. Aide, J. Graesser, D. Edwards, and H.R. Grau. 2019. The neotropical reforestation hotspots: A biophysical and socioeconomic typology of contemporary forest expansion. Global Environmental Change 54: 148-159. https://doi. org/10.1016/j.gloenvcha.2018.12.001.

Navarro, L.M., and H.M. Pereira. 2015. Rewilding Abandoned Landscapes in Europe In Rewilding European Landscapes. Cham: Springer. https://doi.org/10.1007/978-3-319-12039-3.

Parés-Ramos, I.K., W.A. Gould, and T.M. Aide. 2008. Agricultural abandonment, suburban growth, and forest expansion in Puerto Rico between 1991 and 2000. Ecology and Society 13:1. http:// www.ecologyandsociety.org/vol13/iss2/art1/

Paviolo, A., P. Cruz, M.E. Iezzi, J.M. Pardo, D. Varela, C. De Angelo, S. Benito, E. Vanderhoeven, et al. 2018. Barriers, corridors or suitable habitat? Effect of monoculture tree plantations on the habitat use and prey availability for jaguars and pumas in the Atlantic Forest. Forest Ecology and Management 430: 576-586. https://doi.org/10.1016/j.foreco.2018.08.029.

Pliscoff, P., J.A. Simonetti, A.A. Grez, P.M. Vergara, and R.M. Barahona-Segovia. 2020. Defining corridors for movement of multiple species in a forest-plantation landscape. Global Ecology and Conservation 23: e01108. https://doi.org/10.1016/j.gecco. 2020.e01108.

Ravetz, J., C. Fertner, and T.S. Nielsen. 2012. The dynamics of periurbanization. In Peri-Urban Futures: Scenarios and Models for Land Use Change in Europe, ed. K. Nilsson, S. Pauleit, S. Bell, C. Aalbers, and T.A. Sick Nielsen, 13-44. Berlin: Springer. https://doi.org/10.1007/978-3-642-30529-0_2.

Redo, D.J., H.R. Grau, T.M. Aide, and M.L. Clark. 2012. Asymmetric forest transition driven by the interaction of socioeconomic development and environmental heterogeneity in Central America. Proceedings of the National Academy of Sciences 109: 8839-8844. https://doi.org/10.1073/pnas.1201664109.

Rudel, T.K., O.T. Coomes, E. Moran, F. Achard, A. Angelsen, J. Xu, and E. Lambin. 2005. Forest transitions: Towards a global understanding of land use change. Global Environmental Change 15: 23-31. https://doi.org/10.1016/j.gloenvcha.2004.11. 001.

Rudel, T.K., P. Meyfroidt, R. Chazdon, F. Bongers, S. Sloan, H.R. Grau, T. Van Holt, and L. Schneider. 2019. Whither the forest transition? Climate change, policy responses, and redistributed forests in the twenty-first century. Ambio 49: 1-11. https://doi. org/10.1007/s13280-018-01143-0.

Shaw, B.J., J. van Vliet, and P.H. Verburg. 2020. The periurbanization of Europe: A systematic review of a multifaceted process. Landscape and Urban Planning 196: 103733. https:// doi.org/10.1016/j.landurbplan.2019.103733.

Socolar, J.B., J.J. Gilroy, W.E. Kunin, and D.P. Edwards. 2016. How should beta-diversity inform biodiversity conservation? Trends in Ecology and Evolution 31: 67-80. https://doi.org/10.1016/j. tree.2015.11.005.

Soulsbury, C.D., and P.C. White. 2015. Human-wildlife interactions in urban areas: A review of conflicts, benefits and opportunities. Wildlife Research 42: 541-553. https://doi.org/10.1071/ WR14229.

Spear, D., L.C. Foxcroft, H. Bezuidenhout, and M.A. McGeoch. 2013. Human population density explains alien species richness in protected areas. Biological Conservation 159: 137-147. https://doi.org/10.1016/j.biocon.2012.11.022.

Suarez-Rubio, M., P. Leimgruber, and S.C. Renner. 2011. Influence of exurban development on bird species richness and diversity. Journal of Ornithology 152: 461-471. https://doi.org/10.1007/ s10336-010-0605-x.

Sun, D., W. Zhang, Y. Lin, Z. Liu, W. Shen, L. Zhou, X. Rao, S. Liou, et al. 2018. Soil erosion and water retention varies with plantation type and age. Forest Ecology and Management 422: 1-10. https://doi.org/10.1016/j.foreco.2018.03.048.

Sutherland, L.A., and S. Huttunen. 2018. Linking practices of multifunctional forestry to policy objectives: Case studies in Finland and the UK. Forest Policy and Economics 86: 35-44. https://doi.org/10.1016/j.forpol.2017.10.019.

Taylor, L.E., and P.T. Hurley. 2016. Introduction: The broad contours of exurban landscape change. In A Comparative Political Ecology of Exurbia, ed. L.E. Taylor and P.T. Hurley, 1-29. Cham: Springer. https://doi.org/10.1007/978-3-319-29462-9.

Taylor, B.W., and R.E. Irwin. 2004. Linking economic activities to the distribution of exotic plants. Proceedings of the National Academy of Sciences 101: 17725-17730. https://doi.org/10.1073/ pnas.0405176101.

Thomas, C.D. 2015. Rapid acceleration of plant speciation during the Anthropocene. Trends in Ecology \& Evolution 30: 448-455. https://doi.org/10.1016/j.tree.2015.05.009.

Tu, S., H. Long, Y. Zhang, D. Ge, and Y. Qu. 2018. Rural restructuring at village level under rapid urbanization in metropolitan suburbs of China and its implications for innovations in land use policy. Habitat International 77: 143-152. https://doi.org/10.1016/j.habitatint.2017.12.001. 
Van der Sluis, T., B. Pedroli, P. Frederiksen, S.B.P. Kristensen, A. Gravsholt Busck, V. Pavlis, and G.L. Cosor. 2019. The impact of European landscape transitions on the provision of landscape services: An explorative study using six cases of rural land change. Landscape Ecology 34: 307-323. https://doi.org/10. 1007/s10980-018-0765-2.

Vellend, M., L. Baeten, A. Becker-Scarpitta, V. Boucher-Lalonde, J.L. McCune, J. Messier, I.H. Myers-Smith, and D.F. Sax. 2017. Plant biodiversity change across scales during the Anthropocene. Annual Review of Plant Biology 68: 563-586. https://doi.org/10. 1146/annurev-arplant-042916-040949.

Verburg, P.H., N. Crossman, E.C. Ellis, A. Heinimann, P. Hostert, O. Mertz, H. Nagendra, T. Sikor, et al. 2015. Land system science and sustainable development of the earth system: A global land project perspective. Anthropocene 12: 29-41. https://doi.org/10. 1016/j.ancene.2015.09.004.

Wilson, S.J., J. Schelhas, H.R. Grau, A.S. Nanni, and S. Sloan. 2017. Forest ecosystem-service transitions. Ecology and Society 22: 38. https://doi.org/10.5751/ES-09615-220438.

Winter, P.L., S. Selin, L. Cerveny, and K. Bricker. 2020. Outdoor recreation, nature-based tourism, and sustainability. Sustainability 12: 81. https://doi.org/10.3390/su12010081.

Woods, M. 2005. Rural Geography: Processes, Responses and Experiences in Rural Restructuring. London: Sage. https://doi. org/10.4135/9781446216415.

Publisher's Note Springer Nature remains neutral with regard to jurisdictional claims in published maps and institutional affiliations.

\section{AUTHOR BIOGRAPHIES}

Yohana G. Jimenez $(\varangle)$ is a Phd Student at Instituto de Ecología Regional, Argentina. She focuses on understanding socio-economic drivers of land cover changes and their impact on the supply of ecosystem services.

Address: Instituto de Ecología Regional (IER), Universidad Nacional de Tucumán (UNT)- Consejo Nacional de Investigaciones Científicas y Técnicas (CONICET), CC. 34, 4107 Yerba Buena, Tucumán, Argentina.

e-mail: yohanajimenez2406@gmail.com

Ezequiel Aráoz is a researcher at Instituto de Ecología Regional, Argentina. His research addresses the causes and consequences of human intervention in natural environments.

Address: Instituto de Ecología Regional (IER), Universidad Nacional de Tucumán (UNT)- Consejo Nacional de Investigaciones Científicas y Técnicas (CONICET), CC. 34, 4107 Yerba Buena, Tucumán, Argentina.

Address: Facultad de Ciencias Naturales e Instituto Miguel Lillo, Universidad Nacional de Tucumán (UNT), 4000 San Miguel, Tucumán, Argentina.

e-mail: ezequielaraoz@gmail.com

Romina D. Fernandez is a postdoctoral researcher at Instituto de Ecología Regional, Argentina. Her research is focused on the ecology of biological invasions, mainly in understanding how invasive alien plants impact on biodiversity and ecosystem functioning.
Address: Instituto de Ecología Regional (IER), Universidad Nacional de Tucumán (UNT)- Consejo Nacional de Investigaciones Científicas y Técnicas (CONICET), CC. 34, 4107 Yerba Buena, Tucumán, Argentina.

e-mail: romi.d.fernandez@gmail.com

Sofia Nanni is a postdoctoral researcher at Instituto de Ecología Regional, Argentina. Her research focuses on the links between anthropic landuse and change and medium-large mammal conservation at different scales.

Address: Instituto de Ecología Regional (IER), Universidad Nacional de Tucumán (UNT)- Consejo Nacional de Investigaciones Científicas y Técnicas (CONICET), CC. 34, 4107 Yerba Buena, Tucumán, Argentina.

e-mail: sofiananni@gmail.com

Ramiro Ovejero is a researcher at Instituto de Ecología Regional, Horco Molle, Tucuman, Argentina. His interest focused on wildlife ecologists, wildlife management, stress ecology, movement ecology, conservation biology, and wildlife habitat relationship with an emphasis on coexistence framework.

Address: Instituto de Ecología Regional (IER), Universidad Nacional de Tucumán (UNT)- Consejo Nacional de Investigaciones Científicas y Técnicas (CONICET), CC. 34, 4107 Yerba Buena, Tucumán, Argentina.

e-mail: ovejerorama@gmail.com

Leonardo Paolini is a Research Scientist at Instituto de Ecología Regional, Horco Molle, Tucuman, Argentina, and Honorary Academic at The University of Auckland, New Zealand. During the last 15 years, he has led research in forest dynamics in natural and urban ecosystems.

Address: Instituto de Ecología Regional (IER), Universidad Nacional de Tucumán (UNT)- Consejo Nacional de Investigaciones Científicas y Técnicas (CONICET), CC. 34, 4107 Yerba Buena, Tucumán, Argentina.

Address: School of Environment, The University of Auckland, Science Centre 302 - Bldg 302, 23 Symonds St, Auckland, New Zealand. e-mail: 1.paolini@auckland.ac.nz

H. Ricardo Grau for the last 20 years led research on Forest Transition in Latin America and its relationship with human demography, exotic species invasion, and disturbance ecology. He is currently the Director of the Instituto de Ecología Regional, a member of the Scientific Steering Committee of the Global Land Programme and of the Scientific Leadership Council of Mountain Research Initiative.

Address: Instituto de Ecología Regional (IER), Universidad Nacional de Tucumán (UNT)- Consejo Nacional de Investigaciones Científicas y Técnicas (CONICET), CC. 34, 4107 Yerba Buena, Tucumán, Argentina.

Address: Facultad de Ciencias Naturales e Instituto Miguel Lillo, Universidad Nacional de Tucumán (UNT), 4000 San Miguel, Tucumán, Argentina.

e-mail: chilograu@gmail.com

URL: https://ier.conicet.gov.ar/docentes-e-investigadores/ 